\title{
Potential of Induced Pluripotent Stem Cells (iPSCs) for Treating Age-Related Macular Degeneration (AMD)
}

\author{
Mark Fields *, Hui Cai, Jie Gong and Lucian Del Priore \\ Department of Ophthalmology and Visual Science, Yale School of Medicine, Yale University, 300 George St., \\ Suite 8100, New Haven, CT 06511, USA; huey.cai@yale.edu (H.C.); jie.gong@yale.edu (J.G.); \\ lucian.delpriore@yale.edu (L.D.P.) \\ * Correspondence: mark.fields@yale.edu; Tel.: +1-203-785-4282
}

Academic Editor: Giovanni Amabile

Received: 26 October 2016; Accepted: 2 December 2016; Published: 8 December 2016

\begin{abstract}
The field of stem cell biology has rapidly evolved in the last few decades. In the area of regenerative medicine, clinical applications using stem cells hold the potential to be a powerful tool in the treatment of a wide variety of diseases, in particular, disorders of the eye. Embryonic stem cells (ESCs) and induced pluripotent stem cells (iPSCs) are promising technologies that can potentially provide an unlimited source of cells for cell replacement therapy in the treatment of retinal degenerative disorders such as age-related macular degeneration (AMD), Stargardt disease, and other disorders. ESCs and iPSCs have been used to generate retinal pigment epithelium (RPE) cells and their functional behavior has been tested in vitro and in vivo in animal models. Additionally, iPSC-derived RPE cells provide an autologous source of cells for therapeutic use, as well as allow for novel approaches in disease modeling and drug development platforms. Clinical trials are currently testing the safety and efficacy of these cells in patients with AMD. In this review, the current status of iPSC disease modeling of AMD is discussed, as well as the challenges and potential of this technology as a viable option for cell replacement therapy in retinal degeneration.
\end{abstract}

Keywords: age-related macular degeneration; induced pluripotent stem cell; retinal pigment epithelium; Bruch's membrane; disease modeling

\section{Introduction}

Progress in the area of regenerative medicine has begun to unlock new opportunities in the way health care providers approach treatment of debilitating disorders. Efforts to develop viable treatments, such as cell replacement therapy, have begun to become a reality for such disorders as diabetes, Parkinson, Alzheimer, and multiple sclerosis [1,2]. The field of ophthalmology is no different and has seen dramatic advancements in the area of stem cell-based treatments. Therapies are being developed for such visual impairment disorders as age-related macular degeneration (AMD), a leading cause of blindness in the United States and Western Europe, which has a significant impact on the quality of life of affected individuals [3]. Pertinently, a search of www.ClinicalTrials.gov reveals a number of stem cell-based therapies for the treatment of AMD that have progressed to human clinical trials. The main objective of these trials is to test the safety and efficacy of these treatments in patients with AMD [4,5].

The development of induced pluripotent stem cell (iPSC) technology has presented a paradigm shift in the field of stem cell biology and provides an alternative source of pluripotent cells. The pioneering accomplishment in 2006 by the Yamanaka group had very important implications for the field with the novel discovery that differentiated somatic cells can be induced into a pluripotent state using a cocktail of proteins called "Yamanaka factors" [6]. These "reprogrammed" cells, therefore have the ability to be differentiated into any cell type in the body. With this advancement has come 
many concerns, such as ethical use and a continuous source of embryonic stem cells that have hindered clinical development. With reprogrammed cells these concerns are negated and the possibility of developing patient-specific therapies using autologous cells has been introduced.

Induced pluripotent stem cell technology provides a patient-specific source of cells that, from a clinical standpoint, affords a potential cell replacement therapy that may circumvent immune rejection $[7,8]$. The fact that these cells can be directly generated from the patient affords investigators the opportunity to model a specific disease and provides a relevant investigational tool that is an alternative to traditional animal models [9-11]. Use of iPSC-derived cells for disease modeling can allow for the understanding of the pathology and cell biology of retinal diseases such as AMD, and help elucidate the morphological changes attributed to the aging process and progression of disease $[12,13]$. These models can also lead to the development of platforms for drug screening and safety studies. Given the utility of iPSCs, both as a research tool to understand disease pathophysiology and as a therapeutic for cell replacement therapy, their potential continues to be investigated.

We present a review herein of the current state of iPSCs for the treatment of such retinal degenerative diseases as AMD. In particular, the merit of iPSC-derived disease models to understand the pathophysiology of geographic atrophy (GA), as well as the status of ongoing clinical trials using embryonic stem cells (ESCs) or iPSCs as cell sources will be discussed.

\section{AMD and Bruch's Membrane Pathology}

Age-related macular degeneration is a multifactorial disease that affects the outer retina, choriocapillaris, retinal pigment epithelium (RPE), and Bruch's membrane (BM) [14,15]. The disease is characterized by structural changes within BM which then leads to cellular changes in the RPE including loss of RPE cells and the eventual development of advanced forms of the disorder, such as GA.

Traditionally, AMD has been classified into two types, exudative (neovascular or "wet") AMD or atrophic ("dry") AMD [3,15-17]. One of the earliest clinical manifestations of AMD is the focal deposition of acellular, polymorphous debris between the RPE and BM called drusen [15]. With age, drusen can accumulate and eventually cause damage to the native RPE cells disrupting crucial cellular functions such as maintaining the integrity of the retina and choriocapillaris, including phagocytosis of the distal tips of photoreceptor outer segments, transport and isomerization of bleached visual pigments, maintenance of the blood-outer retinal barrier and maintaining perfusion of the subjacent choriocapillaris [18-31].

In atrophic or "dry" AMD, there is a progressive loss of the RPE and subsequent loss of photoreceptors and/or choriocapillaris. The decline of this tissue inevitably leads to loss of vision, observed clinically as central and paracentral scotomas [15,32]. In exudative or "wet" AMD, abnormal expression of angiogenic factors such as vascular endothelial growth factor (VEGF) can cause neovascularization to arise from the neural retina or choriocapillaris within BM eventually finding its way into the subretinal space and/or subretinal pigment epithelium [15,32]. In many cases, the exudative form can progress and lead to severe vision loss, but with the introduction of intravitreal antiangiogenic therapy a new standard of care has become a very effective treatment to slow or reverse vision loss in many individuals $[15,33]$.

The contribution of BM alterations to AMD pathogenesis is significant, particularly in the context of the development of a cell replacement therapy for advanced disease. These alterations include diffuse BM thickening; accumulation of drusen, basal laminar, and basal linear deposits [34,35]; collagen cross-linking in the inner and outer collagen layer; calcification and fragmentation of the elastin layer [36]; and BM lipidization [36-39]. It has also been reported that structural changes within BM precede cellular changes in the RPE by one or two decades $[34,40]$.

Importantly, these age-related changes within BM can potentially have a negative effect on the function of transplanted cells [34-38,40-47]. It has been demonstrated that disease and/or damage within human-aged BM is an important factor that adversely affects transplant survival 
and proliferation. For example, aging of human BM, or damage induced by surgical manipulation of choroidal neovascularization, can reduce the ability of transplanted RPE cells to attach to human BM, survive after transplantation, and proliferate to repopulate this structure [42,45,48,49]. Aging of human $\mathrm{BM}$ also reduces the ability of human RPE cells seeded on this surface to ingest rod outer segments [50]. Thus, it is clear that in the advanced stages of AMD, namely GA, age-related changes to BM can adversely affect the successful transplantation of cells. Interestingly, we have previously shown that non-enzymatic nitration of the basement membrane is a relevant model system to study BM pathology and can affect RPE dysfunction, such as altered VEGF secretion, phagocytic ability, and expression of complement regulatory proteins in a manner that mimics the effects of BM aging in AMD [50-53]. We have further shown that cleaning and coating the surface of BM or nitrite-modified extracellular matrix (ECM) with such proteins as laminin, fibronectin, and vitronectin can reverse the effects of damage associated with an aged and/or diseased BM [52,54]. Current trials have transplanted stem cell-derived RPE as cell suspensions but the pathology of BM may give credence to the use of a scaffold as a substrate that would allow RPE to attach and proliferate as polarized monolayers [55]. These scaffolds can be made of materials that include collagen and poly(lactic-co-glycolic acid) (PLGA) and it has been demonstrated that a basal support membrane is critical to long-term RPE survival after implantation [56]. It will be of interest to determine the most efficient transplantation method as both single cell suspensions and membrane supports show efficacy [56,57].

\section{Induced Pluripotent Stem Cells}

Induced pluripotent stem cell (iPSC) technology was originally developed by Yamanaka and colleagues in 2006 [6]. The group demonstrated that the combination of transcriptional regulators SRY (sex determining region Y)-box 2 (SOX2), octamer-binding transcription factor 3/4 (OCT3/4), kruppel-like factor 4 (Klf4), and Myc (c-MYC) had the ability to reprogram mouse fibroblasts into a pluripotent stem-like state called iPSCs. The combination of these proteins has been coined the "Yamanaka factors" after its inventor. Methods to generate iPSCs have evolved rapidly since the introduction of the technology in 2006 and have been used to reprogram somatic cells from a number of species, including the rat [58], dog [59], rhesus monkey [60], and human [61,62].

A hallmark of these cells is their ability to differentiate into three germ layer cell types (mesoderm, ectoderm, and endoderm) verifying pluripotency $[6,61,63,64]$. Given their pluripotent attributes, these cells can potentially become any cell type in the body, making them a valuable resource in the area of regenerative medicine and disease modeling.

\section{Induced Pluripotent Stem Cell-Derived Retinal Pigment Epithelium}

In advanced atrophic AMD or GA there is a loss of RPE, photoreceptors, and possibly the choriocapillaris in affected areas, which will require the introduction of replacement cells and/or trophic factors to reconstruct the outer retinal anatomy [32]. Loss of vision is typically due to atrophy of the RPE and photoreceptors with secondary loss of the choriocapillaris. The RPE is important for photoreceptor survival and function, and loss of this cell type is involved in the pathophysiology of atrophy in AMD [65]. The rationale for transplantation of RPE cells is clear and the potential for cell-based therapy has been investigated in both animals and humans [66-68].

The use of iPSC-derived RPE cells may provide an unlimited source of cells, an inherent limitation when using other potential sources such as donor adult or fetal RPE cells. Use of patient-specific iPSC-derived RPE cells offers an autologous source of cells that are suitable as a research tool to understand disease mechanisms. Many groups, including ours, have differentiated iPSCs into RPE cells successfully and established reproducible protocols [69-75]. Our laboratory has demonstrated the ability to differentiate a human iPSC line of RPE cells using an established protocol (Figure 1) [69,76]. These cells are morphologically similar to native RPE cells and express RPE-specific markers, such as zonula occludens protein-1 (ZO-1) (Figure 2). These cells also have the potential to perform critical functions such as the ability to process retinoids similar to native RPE. (Figure 3) [76]. The in vivo 
function and safety of iPSC-derived RPE cells have also been demonstrated in animal models of retinal degeneration $[71,77,78]$.

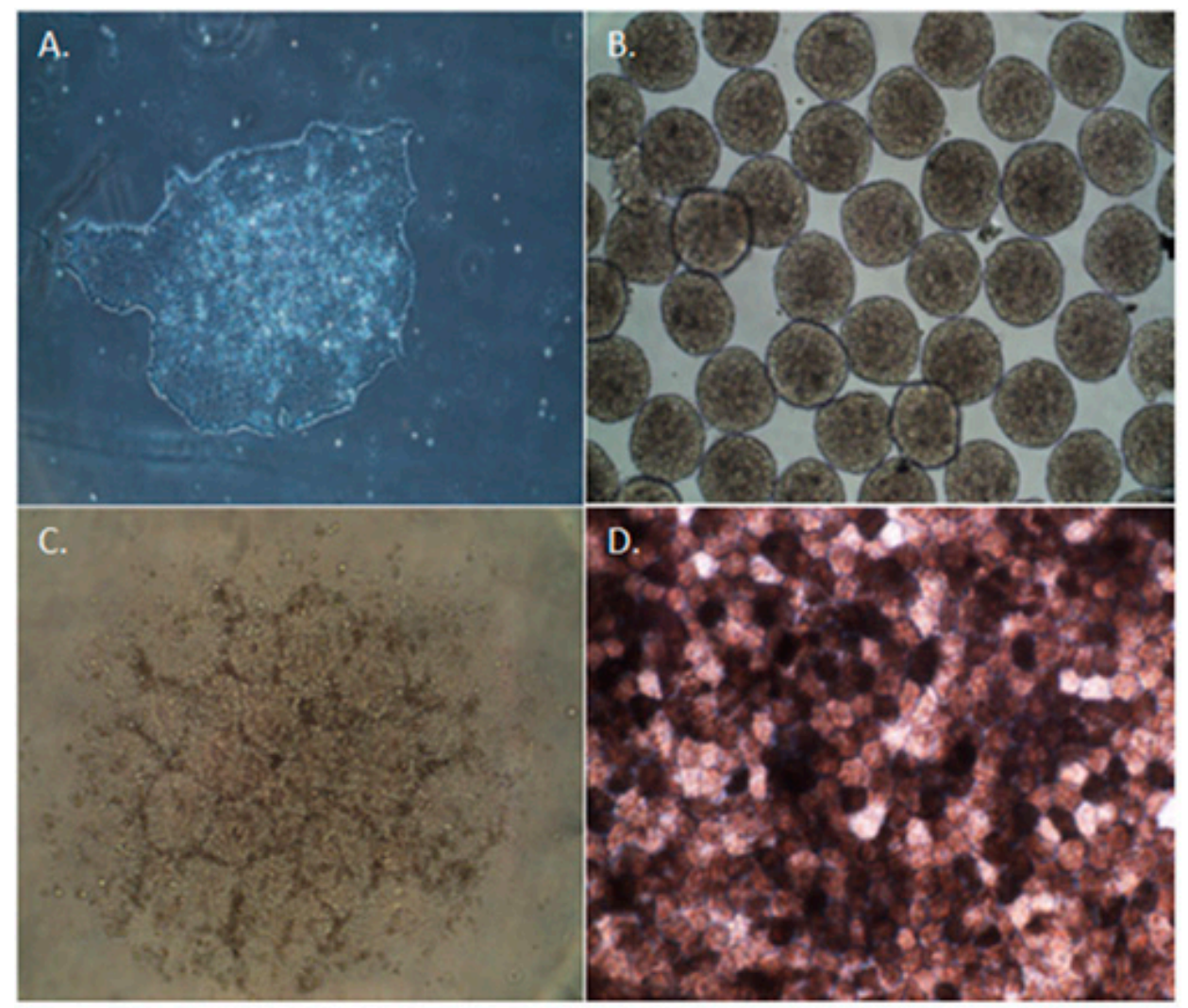

Figure 1. Differentiation of induced pluripotent stem cells (iPSCs) toward a retinal pigment epithelium (RPE) fate. Undifferentiated iPSC colony at day 0 (A); embryonic bodies form by day 7 (B); and eventual formation of neural aggregates (C) by day 14; A pigmented monolayer of iPSC-derived RPE cells forms by day 45 of the differentiation process (D). With the full permission of all authors of the original publication, Figure 3 of [76] has been included here.
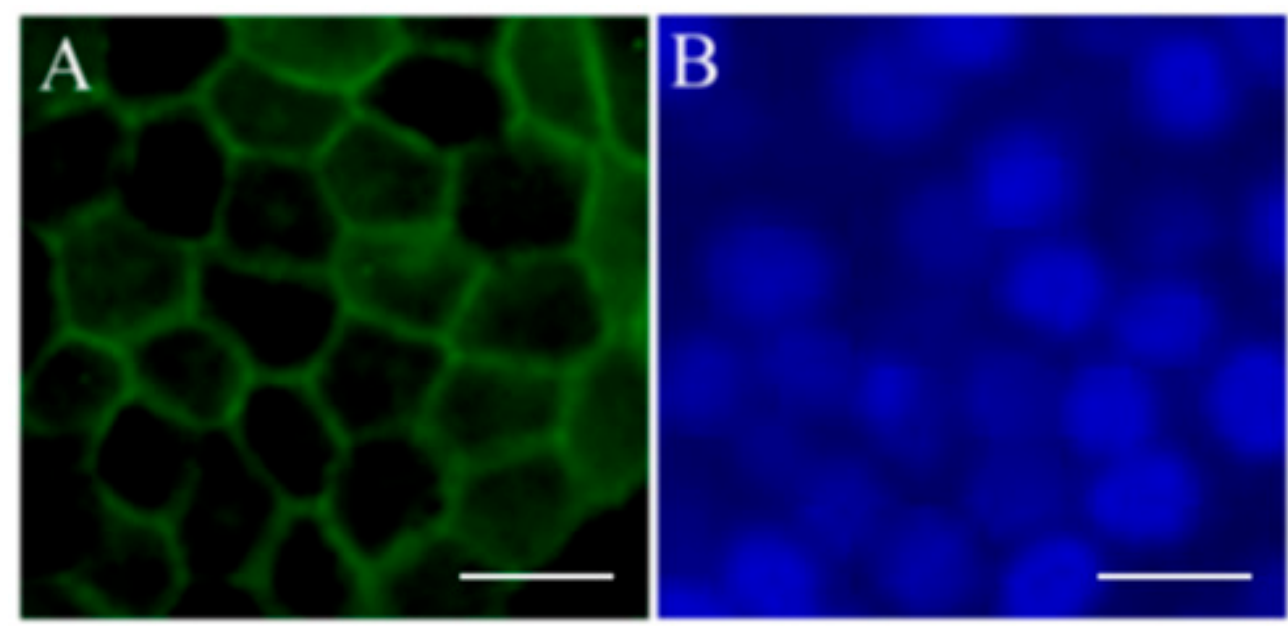

Figure 2. Expression of retinal pigment epithelium (RPE) cell markers in induced pluripotent stem cells (iPSC)-derived RPE. Immunofluorescent staining of RPE marker ZO-1 (A) in pigmented iPSC-derived RPE cells; (B) DAPI image of same cells. Scale bars $=50 \mu \mathrm{m}$. With the full permission of all authors of the original publication, Figure 4 of [76] has been included here. 


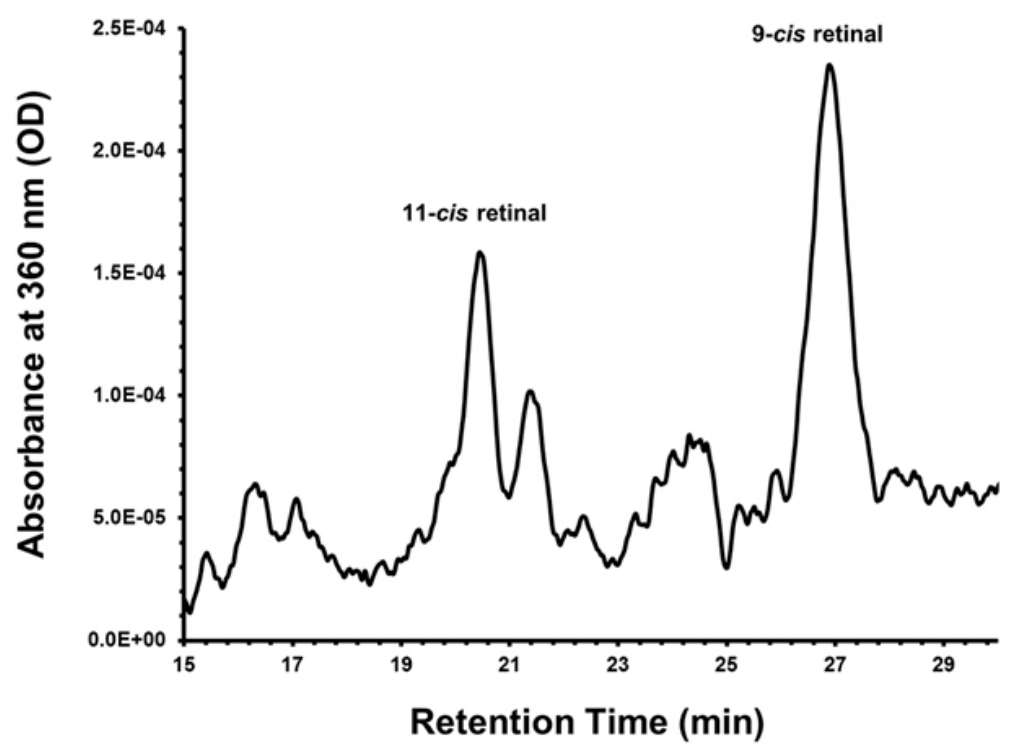

Figure 3. Retinoid metabolism in induced pluripotent stem cell (iPSC)-derived retinal pigment epithelium (RPE) monolayers. iPSC-RPE cells were cultured in 6-well plates until a confluent and pigmented monolayer was observed. Retinoid profiles were taken by monitoring the HPLC at $360 \mathrm{~nm}$, two days post administration of $5 \mu \mathrm{mol} / \mathrm{L}$ all-trans retinol (atRol) in 1\% bovine serum albumin. iPSC-RPE cell cultures express 11-cis-retinal indicating functional retinoid metabolism. No hydroxylamine was used in these experiments; therefore, oximes are not detected. Note that significant quantities of the more stable 9-cis isomer are also formed with the administration of all-trans retinol. With the full permission of all authors of the original publication, Figure 6 of [76] has been included here.

\section{Use of iPSC-Derived RPE to Model Age-Related Macular Degeneration}

As mentioned, one of the advantages of using iPSCs is the ability to model a specific disease in vitro by developing a disease phenotype and intervening through drug screening [79]. Ocular diseases, such as glaucoma and Best disease, have been modeled using iPSCs. These models produced disease phenotypes that have advanced our understanding of the genetics of disease $[80,81]$. For example, Singh et al. demonstrated defective photoreceptor outer segment degradation and disposal as well as reduced fluid transport in iPSC-derived RPE derived from patients with the RPE-specific protein bestrophin-1 (BEST1) mutation [80]. Disease modeling with iPSC derived from monogenic degenerative disorder will benefit greatly from this technology $[9,12]$.

It has been difficult, historically, to model age-related disorders, such as GA, in the animal, particularly in the lower vertebrates such as the mouse who do not have a macula [82]. While animal models are an extremely valuable and indispensable tool for research, developing models of GA using human iPSCs from patients with AMD that could mimic or accelerate the aging process could prove valuable. Moreover, iPSC phenotypes from patients with a particular disease, such as exudative or atrophic AMD, may differ from what is observed in the animal and serve as a valuable source for comparative study $[82,83]$.

Several studies have demonstrated that risk factors such as advanced age, race, and mutations in complement alleles such as complement factor $\mathrm{H}$ are associated with AMD [84]. It is clear that the deleterious effects of drusen accumulation on BM contribute to RPE dysfunction and chronic inflammation [51], which are both hallmarks of AMD pathology. Model systems that mimic the effects of BM aging can be used to determine the contribution of ECM damage on the cellular function and pathology of the overlying RPE cells [51,52,85]. Moreover, the use of patient-specific iPSC-derived RPE cells from patients with high and low risk alleles for AMD may reveal how these alterations contribute to RPE dysfunction and atrophy. This area is particularly valid in light of the disorder 
being an interplay between multiple genetic susceptibility factors and environmental components [86]. Continued advancement in this area will lead to a novel understanding of a multifactorial and complex disease.

\section{Current Status of iPSC Therapies for the Treatment of Retinal Disorders}

The use of iPSCs as an option for cell replacement therapy in humans is the ultimate end-goal of this technology. There are a number of advantages to using iPSCs including alleviation of ethical concerns that have hampered ESC clinical development. Moreover, iPSCs present the opportunity to produce autologous cells and, thus avoid the need to find a human leukocyte antigen (HLA)-compatible cell donor and the need for immunosuppression [87]. Table 1 describes the interventional trials that are currently (2016) cited at the www.ClinicalTrials.gov registry and are now in progress investigating the safety and efficacy of human ESC-derived RPE for the treatment of disorders, such as atrophic AMD and Stargardt macular dystrophy $[65,88,89]$. There are also a number of trials being conducted internationally investigating the safety and efficacy of human ESC-derived RPE in the treatment of exudative and atrophic AMD. As of 2016, leading the way in ongoing trials labeled as "interventional" are such companies as the Astellas Institute for Regenerative Medicine and Pfizer. Groups at The Federal University of São Paulo, the Southwest Hospital (China), Regenerative Patch Technologies, LLC, and Cell Cure Neurosciences Ltd. are sponsoring "interventional" trials that are actively recruiting. Interestingly, the Regenerative Patch Technologies, LLC trial is investigating the use ESC-derived RPE seeded on a polymeric substrate (Table 1). Long-term survival of these cells on these types of substrates will be of great interest in determining the most efficient and efficacious means of transplantation. It should be noted that there are groups investigating the use of other sources of stem cells such as those derived from the human brain and grown as neurospheres (human central nervous system stem cells; HuCNS-SC ${ }^{\circledR}$ ) (Table 2) [90]. Stem Cells, Inc. recently completed a trial that tested the safety and efficacy of HuCNS-SC in the treatment of AMD [89].

Table 1. ESC and iPSC-derived RPE-based cell types in clinical trials for inherited and non-inherited macular degeneration. Study type: Interventional. Last updated 25 October 2016.

\begin{tabular}{|c|c|c|c|c|c|c|}
\hline Sponsor & $\begin{array}{l}\text { Cell Type or } \\
\text { Intervention }\end{array}$ & Condition & $\begin{array}{l}\text { Phase of } \\
\text { Trial }\end{array}$ & $\begin{array}{l}\text { Type of } \\
\text { Delivery } \\
\text { (Intervention) }\end{array}$ & $\begin{array}{l}\text { ClinicalTrials.gov } \\
\text { Identifier }\end{array}$ & Status \\
\hline $\begin{array}{l}\text { Regenerative } \\
\text { Patch } \\
\text { Technologies, } \\
\text { LLC }\end{array}$ & $\begin{array}{l}\text { CPCB-RPE1; human } \\
\text { ESC-derived RPE } \\
\text { seeded on } \\
\text { polymeric substrate }\end{array}$ & $\begin{array}{l}\text { Advanced, dry } \\
\text { age-related } \\
\text { macular } \\
\text { degeneration } \\
\text { (AMD) }\end{array}$ & $\begin{array}{l}\text { Phase I } \\
\text { and II }\end{array}$ & $\begin{array}{l}\text { Subretinal } \\
\text { implantation }\end{array}$ & NCT02590692 & Recruiting \\
\hline $\begin{array}{l}\text { Astellas Institute } \\
\text { for Regenerative } \\
\text { Medicine }\end{array}$ & $\begin{array}{l}\text { MA09-hRPE; } \\
\text { human ESC-derived } \\
\text { RPE }\end{array}$ & $\begin{array}{l}\text { Advanced, dry } \\
\text { age-related } \\
\text { macular } \\
\text { degeneration } \\
\text { (AMD) }\end{array}$ & $\begin{array}{l}\text { Phase I } \\
\text { and II }\end{array}$ & $\begin{array}{l}\text { Subretinal } \\
\text { implantation }\end{array}$ & NCT01344993 & Completed \\
\hline $\begin{array}{l}\text { Astellas Institute } \\
\text { for Regenerative } \\
\text { Medicine }\end{array}$ & $\begin{array}{l}\text { MA09-hRPE; } \\
\text { human ESC-derived } \\
\text { RPE }\end{array}$ & $\begin{array}{l}\text { Stargardt macular } \\
\text { dystrophy (SMD) }\end{array}$ & $\begin{array}{l}\text { Phase I } \\
\text { and II }\end{array}$ & $\begin{array}{l}\text { Subretinal } \\
\text { implantation }\end{array}$ & NCT01469832 & Completed \\
\hline $\begin{array}{l}\text { CHABiotech } \\
\text { Co., Ltd. }\end{array}$ & $\begin{array}{l}\text { MA09-hRPE; } \\
\text { human ESC-derived } \\
\text { RPE }\end{array}$ & $\begin{array}{l}\text { Advanced, dry } \\
\text { age-related } \\
\text { macular } \\
\text { degeneration } \\
\text { (AMD) }\end{array}$ & $\begin{array}{l}\text { Phase I } \\
\text { and II }\end{array}$ & $\begin{array}{l}\text { Subretinal } \\
\text { implantation }\end{array}$ & NCT01674829 & Unknown \\
\hline $\begin{array}{l}\text { Astellas Institute } \\
\text { for Regenerative } \\
\text { Medicine }\end{array}$ & $\begin{array}{l}\text { MA09-hRPE; } \\
\text { human ESC-derived } \\
\text { RPE }\end{array}$ & $\begin{array}{l}\text { Stargardt macular } \\
\text { dystrophy (SMD) }\end{array}$ & $\begin{array}{l}\text { Phase I } \\
\text { and II }\end{array}$ & $\begin{array}{l}\text { Subretinal } \\
\text { implantation }\end{array}$ & NCT01345006 & Completed \\
\hline $\begin{array}{l}\text { University of } \\
\text { California, } \\
\text { Los Angeles }\end{array}$ & $\begin{array}{l}\text { MA09-hRPE; } \\
\text { human ESC-derived } \\
\text { RPE }\end{array}$ & $\begin{array}{l}\text { Myopic macular } \\
\text { degeneration } \\
\text { (MMD) }\end{array}$ & $\begin{array}{l}\text { Phase I } \\
\text { and II }\end{array}$ & $\begin{array}{l}\text { Subretinal } \\
\text { implantation }\end{array}$ & NCT02122159 & Withdrawn \\
\hline
\end{tabular}


Table 1. Cont.

\begin{tabular}{|c|c|c|c|c|c|c|}
\hline Sponsor & $\begin{array}{l}\text { Cell Type or } \\
\text { Intervention }\end{array}$ & Condition & $\begin{array}{l}\text { Phase of } \\
\text { Trial }\end{array}$ & $\begin{array}{l}\text { Type of } \\
\text { Delivery } \\
\text { (Intervention) }\end{array}$ & $\begin{array}{l}\text { ClinicalTrials.gov } \\
\text { Identifier }\end{array}$ & Status \\
\hline $\begin{array}{l}\text { Cell Cure } \\
\text { Neurosciences, } \\
\text { Ltd. }\end{array}$ & $\begin{array}{l}\text { OpRegen: human } \\
\text { ESC-derived RPE }\end{array}$ & $\begin{array}{l}\text { Advanced, } \\
\text { dry-form } \\
\text { age-related } \\
\text { macular } \\
\text { degeneration } \\
\text { (geographic } \\
\text { atrophy, GA) }\end{array}$ & $\begin{array}{l}\text { Phase I } \\
\text { and II }\end{array}$ & $\begin{array}{l}\text { Subretinal } \\
\text { implantation }\end{array}$ & NCT02286089 & Recruiting \\
\hline $\begin{array}{l}\text { CHABiotech } \\
\text { Co., Ltd. }\end{array}$ & $\begin{array}{l}\text { MA09-hRPE; } \\
\text { human ESC-derived } \\
\text { RPE }\end{array}$ & $\begin{array}{l}\text { Stargardt macular } \\
\text { dystrophy (SMD) }\end{array}$ & Phase I & $\begin{array}{l}\text { Subretinal } \\
\text { implantation }\end{array}$ & NCT01625559 & Unknown \\
\hline \multirow{2}{*}{$\begin{array}{l}\text { Federal } \\
\text { University of } \\
\text { São Paulo }\end{array}$} & \multirow{2}{*}{$\begin{array}{l}\text { Human } \\
\text { ESC-derived RPE in } \\
\text { suspension; human } \\
\text { ESC-derived RPE } \\
\text { seeded in a } \\
\text { substrate }\end{array}$} & $\begin{array}{l}\text { Age-related } \\
\text { macular } \\
\text { degeneration }\end{array}$ & \multirow{2}{*}{$\begin{array}{l}\text { Phase I } \\
\text { and II }\end{array}$} & \multirow{2}{*}{$\begin{array}{l}\text { Subretinal } \\
\text { implantation }\end{array}$} & \multirow[b]{2}{*}{ NCT02903576 } & \multirow[b]{2}{*}{ Recruiting } \\
\hline & & $\begin{array}{l}\text { Exudative, } \\
\text { age-related } \\
\text { macular } \\
\text { degeneration }\end{array}$ & & & & \\
\hline \multirow[t]{2}{*}{ Pfizer } & \multirow{2}{*}{$\begin{array}{l}\text { PF-05206388; } \\
\text { human ESC-derived } \\
\text { RPE }\end{array}$} & $\begin{array}{l}\text { Acute, wet } \\
\text { age-related } \\
\text { macular } \\
\text { degeneration }\end{array}$ & \multirow[t]{2}{*}{ Phase I } & \multirow[t]{2}{*}{$\begin{array}{l}\text { Intraocular } \\
\text { implantation }\end{array}$} & \multirow[t]{2}{*}{ NCT01691261 } & \multirow[t]{2}{*}{$\begin{array}{l}\text { Active, not } \\
\text { recruiting }\end{array}$} \\
\hline & & $\begin{array}{l}\text { Rapid vision } \\
\text { decline }\end{array}$ & & & & \\
\hline $\begin{array}{l}\text { Southwest } \\
\text { Hospital, China }\end{array}$ & $\begin{array}{l}\text { Human } \\
\text { ESC-derived RPE }\end{array}$ & $\begin{array}{l}\text { Macular } \\
\text { degeneration, } \\
\text { Stargardt macular } \\
\text { dystrophy }\end{array}$ & Phase I & $\begin{array}{l}\text { Subretinal } \\
\text { transplantation }\end{array}$ & NCT02749734 & Recruiting \\
\hline
\end{tabular}

ESC, embryonic stem cell; iPSC, induced pluripotent stem cell; RPE, retinal pigment epithelium.

Table 2. Stem cell-based cell types for inherited and non-inherited macular degenerations. Study type: Interventional. Last updated 25 October 2016.

\begin{tabular}{|c|c|c|c|c|c|c|}
\hline Sponsor & $\begin{array}{l}\text { Cell Type or } \\
\text { Intervention }\end{array}$ & Condition & Phase of Trial & $\begin{array}{l}\text { Type of } \\
\text { Delivery } \\
\text { (Intervention) }\end{array}$ & $\begin{array}{l}\text { ClinicalTrials.gov } \\
\text { Identifier }\end{array}$ & Status \\
\hline $\begin{array}{l}\text { StemCells, } \\
\text { Inc. }\end{array}$ & $\begin{array}{l}\text { Human central } \\
\text { nervous system } \\
\text { stem cells } \\
\text { (HuCNS-SC) }\end{array}$ & $\begin{array}{l}\text { Geographic atrophy } \\
\text { (GA) of age-related } \\
\text { macular } \\
\text { degeneration } \\
\text { (AMD) }\end{array}$ & Phase I and II & $\begin{array}{l}\text { Subretinal } \\
\text { transplantation }\end{array}$ & NCT01632527 & Completed \\
\hline $\begin{array}{l}\text { University of } \\
\text { São Paulo }\end{array}$ & $\begin{array}{l}\text { Autologous } \\
\text { bone marrow } \\
\text { stem cells }\end{array}$ & $\begin{array}{l}\text { Macular } \\
\text { degeneration }\end{array}$ & Phase I and II & $\begin{array}{l}\text { Intravitreal } \\
\text { injection }\end{array}$ & NCT01518127 & Recruiting \\
\hline $\begin{array}{l}\text { Al-Azhar } \\
\text { University }\end{array}$ & $\begin{array}{l}\text { Autologous } \\
\text { bone marrow } \\
\text { stem cells }\end{array}$ & $\begin{array}{l}\text { Dry, age-related } \\
\text { macular } \\
\text { degeneration } \\
\text { (AMD) }\end{array}$ & Phase I and II & $\begin{array}{l}\text { Intravitreal } \\
\text { injection }\end{array}$ & NCT02016508 & Unknown \\
\hline $\begin{array}{l}\text { Bioheart, } \\
\text { Inc. }\end{array}$ & $\begin{array}{l}\text { Adipose-derived } \\
\text { stem cells }\end{array}$ & $\begin{array}{l}\text { Dry, macular } \\
\text { degeneration }\end{array}$ & Not reported & $\begin{array}{l}\text { Intravitreal } \\
\text { injection }\end{array}$ & NCT02024269 & Withdrawn \\
\hline \multirow{5}{*}{$\begin{array}{l}\text { Retina } \\
\text { Association } \\
\text { of South } \\
\text { Florida }\end{array}$} & \multirow{5}{*}{$\begin{array}{l}\text { Bone-marrow } \\
\text { delivered stem } \\
\text { cells (BMSC) }\end{array}$} & Retinal disease & \multirow{5}{*}{ Not reported } & Retrobulbar & \multirow{5}{*}{ NCT01920867 } & \multirow{5}{*}{ Recruiting } \\
\hline & & $\begin{array}{l}\text { Macular } \\
\text { degeneration }\end{array}$ & & Subtenon & & \\
\hline & & $\begin{array}{l}\text { Hereditary retinal } \\
\text { dystrophy }\end{array}$ & & Intravenous & & \\
\hline & & Optic nerve disease & & Intravitreal & & \\
\hline & & Glaucoma & & Intraocular & & \\
\hline
\end{tabular}


Table 2. Cont.

\begin{tabular}{|c|c|c|c|c|c|c|}
\hline Sponsor & $\begin{array}{l}\text { Cell Type or } \\
\text { Intervention }\end{array}$ & Condition & Phase of Trial & $\begin{array}{l}\text { Type of } \\
\text { Delivery } \\
\text { (Intervention) }\end{array}$ & $\begin{array}{l}\text { ClinicalTrials.gov } \\
\text { Identifier }\end{array}$ & Status \\
\hline \multirow{5}{*}{$\begin{array}{l}\text { University of } \\
\text { California, } \\
\text { Davis }\end{array}$} & \multirow{5}{*}{$\begin{array}{l}\text { CD34 + bone } \\
\text { marrow stem } \\
\text { cells }\end{array}$} & $\begin{array}{l}\text { Non-exudative, } \\
\text { age-related macular } \\
\text { degeneration }\end{array}$ & \multirow{5}{*}{ Phase I } & \multirow{5}{*}{$\begin{array}{l}\text { Intravitreal } \\
\text { injection }\end{array}$} & \multirow{5}{*}{ NCT01736059 } & \multirow{5}{*}{$\begin{array}{l}\text { Enrolled by } \\
\text { invitation }\end{array}$} \\
\hline & & Diabetic retinopathy & & & & \\
\hline & & $\begin{array}{l}\text { Retinal vein } \\
\text { occlusion }\end{array}$ & & & & \\
\hline & & Retinitis pigmentosa & & & & \\
\hline & & $\begin{array}{l}\text { Hereditary macular } \\
\text { degeneration }\end{array}$ & & & & \\
\hline $\begin{array}{l}\text { Red de } \\
\text { Terapia } \\
\text { Celular }\end{array}$ & $\begin{array}{l}\text { Autologous } \\
\text { bone marrow } \\
\text { stem cells }\end{array}$ & Retinitis pigmentosa & Phase I & $\begin{array}{l}\text { Intravitreal } \\
\text { injection; } \\
\text { subconjunctival } \\
\text { injection of } \\
\text { saline }\end{array}$ & NCT02280135 & Recruiting \\
\hline $\begin{array}{l}\text { StemCells, } \\
\text { Inc. }\end{array}$ & $\begin{array}{l}\text { Human central } \\
\text { nervous system } \\
\text { stem cells } \\
\text { (HuCNS-SC) }\end{array}$ & $\begin{array}{l}\text { Age-related macular } \\
\text { degeneration }\end{array}$ & Phase II & $\begin{array}{l}\text { Subretinal } \\
\text { transplantation }\end{array}$ & NCT02467634 & $\begin{array}{l}\text { Terminated; } \\
\text { based on a } \\
\text { business } \\
\text { decision } \\
\text { unrelated to any } \\
\text { safety concerns }\end{array}$ \\
\hline
\end{tabular}

Current efforts to conduct clinical trials using iPSC-derived RPE have been extremely limited. To date, there has been one trial attempt to treat exudative AMD using autologous iPSC-derived RPE cells [65,88,89,91,92]. In 2014, a Japanese woman with exudative macular degeneration was implanted with an iPSC-derived RPE sheet generated from her own fibroblasts [93]. Even though the first patient suffered "no serious adverse effects" of treatment, the trial has been put on hold due to the discovery of genetic mutations identified in the iPSCs that were to be used in a second patient in 2015 [94,95]. While it is not clear whether these genetic abnormalities were induced during the reprogramming process or originated from the patient's somatic cells, these genomic instabilities must be evaluated before entering human trials. Moving forward, one goal of Sugita et al., is to use iPSCs from partially-matched donors rather than the autologous cells from the same individual to avoid the potential of genomic abnormalities. Sugita and colleagues have demonstrated that cells from major histocompatibility complex (MHC) homozygous donors can be used in histocompatible recipients for treatment of retinal disease [96]. In that study, investigators transplanted iPSC-derived RPE cells in MHC homozygous animals and found no immune response or rejection of iPSC-derived RPE allografts when using MHC-matched animal models without immunosuppression. These studies show that if the donor is MHC or HLA-matched, iPSC-derived RPE cell donor transplantation may be successful with little to no immunosuppression [96,97]. These promising results for iPSC-derived cell types are continuing to be investigated. It has recently been reported that the Riken Center for Developmental Biology will resume its clinical trial using donor cells [98].

While there is much promise in moving iPSC technology to clinical applications, there is still work to be done in our understanding of tumorigenicity and cell survival post-transplantation before entering the human. Work done by Kanemura et al., has demonstrated in animal models that the tumorigenic potential of iPSC-derived RPE is negligible in rodent models. More in vivo studies will need to be conducted [99]. The initial iPSC lines will have to be extensively characterized, particularly in light of the U.S. Food and Drug Administration (FDA) and regulatory approval to ensure safety. Given that the FDA classifies pluripotent stem cells as human cellular and tissue products that are "more than minimally manipulated and used in a non-homologous manner", it is critical that the issues as discussed above be addressed before iPSC therapies progress to Phase I-III clinical trials [100]. Table 3 describes examples of "observational" trials investigating the feasibility for use of iPSC-derived 
RPE cells for the treatment of various types of macular degeneration. In addition to the above concerns, the issue of cost must be addressed given the extensive amount of time and resources to develop lines and then test safety [94]. As the technology develops this cost may be greatly reduced.

Table 3. iPSC-derived RPE-based studies for inherited and non-inherited macular degenerations. Study type: Observational. Last updated 25 October 2016.

\begin{tabular}{|c|c|c|c|c|c|}
\hline Sponsor & Cell Type & Condition & $\begin{array}{l}\text { ClinicalTrials.gov } \\
\text { Identifier }\end{array}$ & Status & Objective \\
\hline $\begin{array}{l}\text { Moorfields Eye } \\
\text { Hospital }\end{array}$ & \multirow{2}{*}{$\begin{array}{l}\text { Human } \\
\text { iPSC-derived } \\
\text { RPE }\end{array}$} & \multirow[t]{2}{*}{$\begin{array}{l}\text { Age-related macular } \\
\text { degeneration }\end{array}$} & \multirow[t]{2}{*}{ NCT02464956 } & \multirow[t]{2}{*}{$\begin{array}{l}\text { Not yet } \\
\text { recruiting }\end{array}$} & \multirow{2}{*}{$\begin{array}{l}\text { Successful production of a retinal } \\
\text { epithelial layer of cells that fulfills } \\
\text { Regulatory Regulation for } \\
\text { Transplantation. }\end{array}$} \\
\hline $\begin{array}{l}\text { NHS Foundation } \\
\text { Trust }\end{array}$ & & & & & \\
\hline \multirow{3}{*}{ Mayo Clinic } & \multirow{3}{*}{$\begin{array}{l}\text { Human } \\
\text { iPSC-derived } \\
\text { RPE }\end{array}$} & $\begin{array}{l}\text { Autosomal recessive } \\
\text { bestrophinopathy (ARB) }\end{array}$ & \multirow{3}{*}{ NCT02162953 } & \multirow{3}{*}{ Recruiting } & \multirow{3}{*}{$\begin{array}{l}\text { To collect DNA, RNA, and skin } \\
\text { samples from individuals with } \\
\text { ARB or other diseases due to } \\
\text { mutations in the gene BEST1. } \\
\text { These models will be used to } \\
\text { identify and test therapeutic } \\
\text { approaches to treating } \\
\text { these diseases. }\end{array}$} \\
\hline & & $\begin{array}{l}\text { Adult-onset vitelliform } \\
\text { dystrophy (AVMD) }\end{array}$ & & & \\
\hline & & $\begin{array}{l}\text { Autosomal dominant } \\
\text { vitreoretinalchoroidopathy } \\
\text { (ADVIRC) }\end{array}$ & & & \\
\hline
\end{tabular}

iPSC, induced pluripotent stem cell; RPE, retinal pigment epithelium; NHS, National Health Service (of England); ARB, angiotensin receptor blockers; L-ORD, late-onset retinal degeneration; AMD, age-related macular degeneration.

\section{Conclusions}

The use of induced pluripotent stem cells for the treatment of age-related macular degeneration holds great potential, but there are still important obstacles that must be addressed. iPSC technology has afforded novel understanding in the area of retinal degeneration through autologous iPSC development and disease modeling. Moving forward, it will be important to optimize reprogramming methods, develop efficient methods to produce large numbers of cells ready for clinical use, test safety and integrity, and understand the long-term survival profiles of cells post-transplantation. Even with these current limitations, the 2006 discovery has the unique opportunity to make new inroads in regenerative medicine and change the face of the field.

Acknowledgments: This work has been supported in part by an unrestricted/challenge award to Yale Eye Center from the Research to Prevent Blindness (RPB), Inc., New York, NY, USA; and the Foundation Fighting Blindness, Columbia, MD, USA. The authors would like to thank Luanna Bartholomew for her intellectual contribution and critical review of this manuscript.

Author Contributions: M.F. conceived and designed the experiments, analyzed the data, contributed reagents/materials/analysis tools, wrote the paper; H.C. conceived and designed the experiments, analyzed data; J.G. conceived and designed the experiments, performed experiments; L.D.P. conceived and designed the experiments, analyzed the data, contributed reagents/materials/analysis tools.

Conflicts of Interest: The authors declare no conflict of interest.

\section{Abbreviations}

$\begin{array}{ll}\text { iPSC } & \text { Induced pluripotent stem cell } \\ \text { AMD } & \text { Age-related macular degeneration } \\ \text { RPE } & \text { Retinal pigment epithelium } \\ \text { ESC } & \text { Embryonic stem cell } \\ \text { BM } & \text { Bruch's membrane } \\ \text { ZO-1 } & \text { Zonula occludens protein-1 } \\ \text { GA } & \text { Geographic atrophy } \\ \text { HLA } & \text { Human leukocyte antigen }\end{array}$




$\begin{array}{ll}\text { MHC } & \text { Major histocompatibility } \\ \text { FDA } & \text { U.S. Food and Drug Administration } \\ \text { ECM } & \text { Extracellular matrix } \\ \text { VEGF } & \text { Vascular endothelial growth factor } \\ \text { SOX2 } & \text { (Sex determining region Y)-box 2 } \\ \text { OCT3/4 } & \text { Octamer-binding transcription factor 3/4 } \\ \text { Klf4 } & \text { Kruppel-like factor 4 } \\ \text { c-MYC } & \text { Regulator gene that codes for a transcription factor; Myc } \\ \text { BEST1 } & \text { RPE-specific protein bestrophin-1 }\end{array}$

\section{References}

1. Cheng, S.K.; Park, E.Y.; Pehar, A.; Rooney, A.C.; Gallicano, G.I. Current Progress of Human Trials Using Stem Cell Therapy as a Treatment for Diabetes Mellitus. Am. J. Stem Cells 2016, 5, 74-86. [PubMed]

2. Kumar, A.; Narayanan, K.; Chaudhary, R.K.; Mishra, S.; Kumar, S.; Vinoth, K.J.; Padmanabhan, P.; Gulyas, B. Current Perspective of Stem Cell Therapy in Neurodegenerative and Metabolic Diseases. Mol. Neurobiol. 2016. [CrossRef] [PubMed]

3. Friedman, D.S.; O'Colmain, B.J.; Munoz, B.; Tomany, S.C.; McCarty, C.; de Jong, P.T.; Nemesure, B.; Mitchell, P.; Kempen, J. Prevalence of Age-Related Macular Degeneration in the United States. Arch. Ophthalmol. 2004, 122, 564-572. [PubMed]

4. Schwartz, S.D.; Regillo, C.D.; Lam, B.L.; Eliott, D.; Rosenfeld, P.J.; Gregori, N.Z.; Hubschman, J.P.; Davis, J.L.; Heilwell, G.; Spirn, M.; et al. Human Embryonic Stem Cell-Derived Retinal Pigment Epithelium in Patients with Age-Related Macular Degeneration and Stargardt's Macular Dystrophy: Follow-Up of Two Open-Label Phase 1/2 Studies. Lancet 2014, 385, 509-516. [CrossRef]

5. Schwartz, S.D.; Hubschman, J.P.; Heilwell, G.; Franco-Cardenas, V.; Pan, C.K.; Ostrick, R.M.; Mickunas, E.; Gay, R.; Klimanskaya, I.; Lanza, R. Embryonic Stem Cell Trials for Macular Degeneration: A Preliminary Report. Lancet 2012, 379, 713-720. [CrossRef]

6. Takahashi, K.; Yamanaka, S. Induction of Pluripotent Stem Cells from Mouse Embryonic and Adult Fibroblast Cultures by Defined Factors. Cell 2006, 126, 663-676. [CrossRef] [PubMed]

7. Araki, R.; Uda, M.; Hoki, Y.; Sunayama, M.; Nakamura, M.; Ando, S.; Sugiura, M.; Ideno, H.; Shimada, A.; Nifuji, A.; et al. Negligible Immunogenicity of Terminally Differentiated Cells Derived from Induced Pluripotent or Embryonic Stem Cells. Nature 2013, 494, 100-104. [CrossRef] [PubMed]

8. Guha, P.; Morgan, J.W.; Mostoslavsky, G.; Rodrigues, N.P.; Boyd, A.S. Lack of Immune Response to Differentiated Cells Derived from Syngeneic Induced Pluripotent Stem Cells. Cell Stem Cell 2013, 12, 407-412. [CrossRef] [PubMed]

9. Inoue, H.; Nagata, N.; Kurokawa, H.; Yamanaka, S. iPS Cells: A Game Changer for Future Medicine. EMBO J. 2014, 33, 409-417. [CrossRef] [PubMed]

10. Okano, H.; Yamanaka, S. iPS Cell Technologies: Significance and Applications to CNS Regeneration and Disease. Mol. Brain 2014, 7, 22. [CrossRef] [PubMed]

11. Inoue, H.; Yamanaka, S. The Use of Induced Pluripotent Stem Cells in Drug Development. Clin. Pharmacol. Ther. 2011, 89, 655-661. [CrossRef] [PubMed]

12. Song, M.J.; Bharti, K. Looking into the Future: Using Induced Pluripotent Stem Cells to Build Two and Three Dimensional Ocular Tissue for Cell Therapy and Disease Modeling. Brain Res. 2016, 1638 Pt A, 2-14. [CrossRef] [PubMed]

13. Li, Y.; Chan, L.; Nguyen, H.V.; Tsang, S.H. Personalized Medicine: Cell and Gene Therapy Based on Patient-Specific iPSC-Derived Retinal Pigment Epithelium Cells. Adv. Exp. Med. Biol. 2016, 854, 549-555. [PubMed]

14. Cai, H.; Del Priore, L.V. Bruch Membrane Aging Alters the Gene Expression Profile of Human Retinal Pigment Epithelium. Curr. Eye Res. 2006, 31, 181-189. [CrossRef] [PubMed]

15. Jager, R.D.; Mieler, W.F.; Miller, J.W. Age-Related Macular Degeneration. N. Engl. J. Med. 2008, 358, $2606-2617$. [CrossRef] [PubMed]

16. Bressler, N.M.; Bressler, S.B.; Fine, S.L. Age-Related Macular Degeneration. Surv. Ophthalmol. 1988, 32, 375-413. [CrossRef] 
17. Bressler, N.M.; Bressler, S.B.; Seddon, J.M.; Gragoudas, E.S.; Jacobson, L.P. Drusen Characteristics in Patients with Exudative Versus Non-Exudative Age-Related Macular Degeneration. Retina 1988, 8, 109-114. [CrossRef] [PubMed]

18. Zinn, K.M.; Marmor, M.F. The Retinal Pigment Epithelium; Harvard University Press: Cambridge, UK, 1979.

19. Miller, F.S., III; Bunt-Milam, A.H.; Kalina, R.E. Clinical-Ultrastructural Study of Thioridazine Retinopathy. Ophthalmology 1982, 89, 1478-1488. [CrossRef]

20. Kuwabara, T.; Ishikawa, Y.; Kaiser-Kupfer, M.I. Experimental Model of Gyrate Atrophy in Animals. Ophthalmology 1981, 88, 331-335. [CrossRef]

21. Henkind, P.; Gartner, S. The Relationship between Retinal Pigment Epithelium and the Choriocapillaris. Trans. Ophthalmol. Soc. U. K. 1983, 103 Pt 4, 444-447. [PubMed]

22. Korte, G.E.; Reppucci, V.; Henkind, P. RPE Destruction Causes Choriocapillary Atrophy. Investig. Ophthalmol. Vis. Sci. 1984, 25, 1135-1145.

23. Takeuchi, M.; Itagaki, T.; Okuma, H.; Takahashi, K.; Uyama, M. Retinal Degeneration after Intravitreal Injection of Ornithine. 2. Late Change after Administration. Nippon Ganka Gakkai Zasshi 1992, 96, 161-168. [PubMed]

24. Takeuchi, M.; Itagaki, T.; Takahashi, K.; Ohkuma, H.; Uyama, M. Changes in the Intermediate Stage of Retinal Degeneration after Intravitreal Injection of Ornithine. Nippon Ganka Gakkai Zasshi 1993, 97, 17-28. [PubMed]

25. Nasir, M.A.; Sugino, I.; Zarbin, M.A. Decreased Choriocapillaris Perfusion Following Surgical Excision of Choroidal Neovascular Membranes in Age-Related Macular Degeneration. Br. J. Ophthalmol. 1997, 81, 481-489. [CrossRef] [PubMed]

26. Pollack, J.S.; Del Priore, L.V.; Smith, M.E.; Feiner, M.A.; Kaplan, H.J. Postoperative Abnormalities of the Choriocapillaris in Exudative Age-Related Macular Degeneration. Br. J. Ophthalmol. 1996, 80, 314-318. [CrossRef] [PubMed]

27. Desai, V.N.; Del Priore, L.V.; Kaplan, H.J. Choriocapillaris Atrophy after Submacular Surgery in Presumed Ocular Histoplasmosis Syndrome. Arch. Ophthalmol. 1995, 113, 408-409. [CrossRef] [PubMed]

28. Leonard, D.S.; Zhang, X.G.; Panozzo, G.; Sugino, I.K.; Zarbin, M.A. Clinicopathologic Correlation of Localized Retinal Pigment Epithelium Debridement. Investig. Ophthalmol. Vis. Sci. 1997, 38, 1094-1109.

29. Del Priore, L.V.; Hornbeck, R.; Kaplan, H.J.; Jones, Z.; Valentino, T.L.; Mosinger-Ogilvie, J.; Swinn, M. Debridement of the Pig Retinal Pigment Epithelium In Vivo. Arch. Ophthalmol. 1995, 113, 939-944. [CrossRef] [PubMed]

30. Valentino, T.L.; Kaplan, H.J.; Del Priore, L.V.; Fang, S.R.; Berger, A.; Silverman, M.S. Retinal Pigment Epithelial Repopulation in Monkeys after Submacular Surgery. Arch. Ophthalmol. 1995, 113, 932-938. [CrossRef] [PubMed]

31. Del Priore, L.V.; Kaplan, H.J.; Hornbeck, R.; Jones, Z.; Swinn, M. Retinal Pigment Epithelial Debridement as a Model for the Pathogenesis and Treatment of Macular Degeneration. Am. J. Ophthalmol. 1996, 122, 629-643. [CrossRef]

32. Fields, M.A.; Hwang, J.; Gong, J.; Cai, H.; Del Priore, L.V. The Eye as a Target Organ for Stem Cell Therapy. In Stem Cell Biology and Regenerative Medicine in Ophthalmology; Stephen, H.T., Ed.; Springer: New York, NY, USA, 2013; pp. 1-30.

33. Amadio, M.; Govoni, S.; Pascale, A. Targeting VEGF in Eye Neovascularization: What's New?: A Comprehensive Review on Current Therapies and Oligonucleotide-Based Interventions under Development. Pharmacol. Res. 2016, 103, 253-269. [CrossRef] [PubMed]

34. Pauleikhoff, D.; Harper, C.A.; Marshall, J.; Bird, A.C. Aging Changes in Bruch's Membrane. A Histochemical and Morphologic Study. Ophthalmology 1990, 97, 171-178. [CrossRef]

35. Sarks, S.H.; Arnold, J.J.; Killingsworth, M.C.; Sarks, J.P. Early Drusen Formation in the Normal and Aging Eye and Their Relation to Age Related Maculopathy: A Clinicopathological Study. Br. J. Ophthalmol. 1999, 83, 358-368. [CrossRef] [PubMed]

36. Spraul, C.W.; Lang, G.E.; Grossniklaus, H.E.; Lang, G.K. Histologic and Morphometric Analysis of the Choroid, Bruch's Membrane, and Retinal Pigment Epithelium in Postmortem Eyes with Age-Related Macular Degeneration and Histologic Examination of Surgically Excised Choroidal Neovascular Membranes. Surv. Ophthalmol. 1999, 44 (Suppl. S1), S10-S32. [CrossRef] 
37. Abdelsalam, A.; Del Priore, L.; Zarbin, M.A. Drusen in Age-Related Macular Degeneration: Pathogenesis, Natural Course, and Laser Photocoagulation-Induced Regression. Surv. Ophthalmol. 1999, 44, 1-29. [CrossRef]

38. Mullins, R.F.; Aptsiauri, N.; Hageman, G.S. Structure and Composition of Drusen Associated with Glomerulonephritis: Implications for the Role of Complement Activation in Drusen Biogenesis. Eye 2001, 15 Pt 3, 390-395. [CrossRef] [PubMed]

39. Curcio, C.A.; Johnson, M.; Rudolf, M.; Huang, J.D. The Oil Spill in Ageing Bruch Membrane. Br. J. Ophthalmol. 2011, 95, 1638-1645. [CrossRef] [PubMed]

40. Marshall, G.E.; Konstas, A.G.; Reid, G.G.; Edwards, J.G.; Lee, W.R. Type IV Collagen and Laminin in Bruch's Membrane and Basal Linear Deposit in the Human Macula. Br. J. Ophthalmol. 1992, 76, 607-614. [CrossRef] [PubMed]

41. Caldwell, R.B. Extracellular Matrix Alterations Precede Vascularization of the Retinal Pigment Epithelium in Dystrophic Rats. Curr. Eye Res. 1989, 8, 907-921. [PubMed]

42. Del Priore, L.V.; Tezel, T.H. Reattachment Rate of Human Retinal Pigment Epithelium to Layers of Human Bruch's Membrane. Arch. Ophthalmol. 1998, 116, 335-341. [CrossRef] [PubMed]

43. Ho, T.C.; Del Priore, L.V. Reattachment of Cultured Human Retinal Pigment Epithelium to Extracellular Matrix and Human Bruch's Membrane. Investig. Ophthalmol. Vis. Sci. 1997, 38, 1110-1118.

44. Tezel, T.H.; Del Priore, L.V. Reattachment to a Substrate Prevents Apoptosis of Human Retinal Pigment Epithelium. Graefes Arch. Clin. Exp. Ophthalmol. 1997, 235, 41-47. [CrossRef] [PubMed]

45. Tezel, T.H.; Del Priore, L.V. TGF Beta Secretion Modulates the Density-Dependent Growth of Pig Retinal Pigment Epithelium In Vitro. Ophthalmic. Res. 1999, 31, 192-202. [CrossRef] [PubMed]

46. Gullapalli, V.K.; Sugino, I.K.; van Patten, Y.; Shah, S.; Zarbin, M.A. Impaired RPE Survival on Aged Submacular Human Bruch's Membrane. Exp. Eye Res. 2005, 80, 235-248. [CrossRef] [PubMed]

47. Wang, H.; Yagi, F.; Cheewatrakoolpong, N.; Sugino, I.K.; Zarbin, M.A. Short-Term Study of Retinal Pigment Epithelium Sheet Transplants onto Bruch's Membrane. Exp. Eye Res. 2004, 78, 53-65. [CrossRef] [PubMed]

48. Tezel, T.H.; Del Priore, L.V. Repopulation of Different Layers of Host Human Bruch's Membrane by Retinal Pigment Epithelial Cell Grafts. Investig. Ophthalmol. Vis. Sci. 1999, 40, 767-774.

49. Castellarin, A.A.; Sugino, I.K.; Vargas, J.A.; Parolini, B.; Lui, G.M.; Zarbin, M.A. In Vitro Transplantation of Fetal Human Retinal Pigment Epithelial Cells onto Human Cadaver Bruch's Membrane. Exp. Eye Res. 1998, 66, 49-67. [CrossRef] [PubMed]

50. Moreira, E.F.; Cai, H.; Tezel, T.H.; Fields, M.A.; Del Priore, L.V. Reengineering Human Bruch's Membrane Increases Rod Outer Segment Phagocytosis by Human Retinal Pigment Epithelium. Transl. Vis. Sci. Technol. 2015, 4, 10. [CrossRef] [PubMed]

51. Wang, Z.; Paik, D.C.; Del Priore, L.V.; Burch, R.L.; Gaillard, E.R. Nitrite-Modified Extracellular Matrix Proteins Deleteriously Affect Retinal Pigment Epithelial Cell Function and Viability: A Comparison Study with Nonenzymatic Glycation Mechanisms. Curr. Eye Res. 2005, 30, 691-702. [CrossRef] [PubMed]

52. Fields, M.A.; Cai, H.; Bowrey, H.E.; Moreira, E.F.; Gooz, M.B.; Kunchithapautham, K.; Gong, J.; Vought, E.; Del Priore, L.V. Nitrite Modification of Extracellular Matrix Alters CD46 Expression and VEGF Release in Human Retinal Pigment Epithelium. Investig. Ophthalmol. Vis. Sci. 2015, 56, 4231-4238. [CrossRef] [PubMed]

53. McLaughlin, B.J.; Fan, W.; Zheng, J.J.; Cai, H.; Del Priore, L.V.; Bora, N.S.; Kaplan, H.J. Novel Role for a Complement Regulatory Protein (CD46) in Retinal Pigment Epithelial Adhesion. Investig. Ophthalmol. Vis. Sci. 2003, 44, 3669-3674. [CrossRef]

54. Tezel, T.H.; Del Priore, L.V.; Kaplan, H.J. Reengineering of Aged Bruch's Membrane to Enhance Retinal Pigment Epithelium Repopulation. Investig. Ophthalmol. Vis. Sci. 2004, 45, 3337-3348. [CrossRef] [PubMed]

55. Warnke, P.H.; Alamein, M.; Skabo, S.; Stephens, S.; Bourke, R.; Heiner, P.; Liu, Q. Primordium of an Artificial Bruch's Membrane Made of Nanofibers for Engineering of Retinal Pigment Epithelium Cell Monolayers. Acta Biomater. 2013, 9, 9414-9422. [CrossRef] [PubMed]

56. Diniz, B.; Thomas, P.; Thomas, B.; Ribeiro, R.; Hu, Y.; Brant, R.; Ahuja, A.; Zhu, D.; Liu, L.; Koss, M.; et al. Subretinal Implantation of Retinal Pigment Epithelial Cells Derived from Human Embryonic Stem Cells: Improved Survival When Implanted as a Monolayer. Investig. Ophthalmol. Vis. Sci. 2013, 54, 5087-5096. [CrossRef] [PubMed] 
57. Reyes, A.P.; Petrus-Reurer, S.; Antonsson, L.; Stenfelt, S.; Bartuma, H.; Panula, S.; Mader, T.; Douagi, I.; Andre, H.; Hovatta, O.; et al. Xeno-Free and Defined Human Embryonic Stem Cell-Derived Retinal Pigment Epithelial Cells Functionally Integrate in a Large-Eyed Preclinical Model. Stem Cell Reports 2016, 6, 9-17.

58. Liao, J.; Cui, C.; Chen, S.; Ren, J.; Chen, J.; Gao, Y.; Li, H.; Jia, N.; Cheng, L.; Xiao, H.; Xiao, L. Generation of Induced Pluripotent Stem Cell Lines from Adult Rat Cells. Cell Stem Cell 2009, 4, 11-15. [CrossRef] [PubMed]

59. Shimada, H.; Nakada, A.; Hashimoto, Y.; Shigeno, K.; Shionoya, Y.; Nakamura, T. Generation of Canine Induced Pluripotent Stem Cells by Retroviral Transduction and Chemical Inhibitors. Mol. Reprod. Dev. 2010, 77, 2. [CrossRef] [PubMed]

60. Liu, H.; Zhu, F.; Yong, J.; Zhang, P.; Hou, P.; Li, H.; Jiang, W.; Cai, J.; Liu, M.; Cui, K.; et al. Generation of Induced Pluripotent Stem Cells from Adult Rhesus Monkey Fibroblasts. Cell Stem Cell 2008, 3, 587-590. [CrossRef] [PubMed]

61. Takahashi, K.; Tanabe, K.; Ohnuki, M.; Narita, M.; Ichisaka, T.; Tomoda, K.; Yamanaka, S. Induction of Pluripotent Stem Cells from Adult Human Fibroblasts by Defined Factors. Cell 2007, 131, 861-872. [CrossRef] [PubMed]

62. Li, J.; Song, W.; Pan, G.; Zhou, J. Advances in Understanding the Cell Types and Approaches Used for Generating Induced Pluripotent Stem Cells. J. Hematol. Oncol. 2014, 7, 50. [CrossRef] [PubMed]

63. Okita, K.; Nakagawa, M.; Hyenjong, H.; Ichisaka, T.; Yamanaka, S. Generation of Mouse Induced Pluripotent Stem Cells without Viral Vectors. Science 2008, 322, 949-953. [CrossRef] [PubMed]

64. Yamanaka, S. A Fresh Look at iPS Cells. Cell 2009, 137, 13-17. [CrossRef] [PubMed]

65. Wu, N.; Doorenbos, M.; Chen, D.F. Induced Pluripotent Stem Cells: Development in the Ophthalmologic Field. Stem Cells Int. 2016, 2016, 2361763. [CrossRef] [PubMed]

66. Tezel, T.H.; Del Priore, L.V.; Berger, A.S.; Kaplan, H.J. Adult Retinal Pigment Epithelial Transplantation in Exudative Age-Related Macular Degeneration. Am. J. Ophthalmol. 2007, 143, 584-595. [CrossRef] [PubMed]

67. Del Priore, L.V.; Kaplan, H.J.; Tezel, T.H.; Hayashi, N.; Berger, A.S.; Green, W.R. Retinal Pigment Epithelial Cell Transplantation after Subfoveal Membranectomy in Age-Related Macular Degeneration: Clinicopathologic Correlation. Am. J. Ophthalmol. 2001, 131, 472-480. [CrossRef]

68. Schwartz, S.D.; Tan, G.; Hosseini, H.; Nagiel, A. Subretinal Transplantation of Embryonic Stem Cell-Derived Retinal Pigment Epithelium for the Treatment of Macular Degeneration: An Assessment at 4 Years. Investig. Ophthalmol. Vis. Sci. 2016, 57, ORSFc1-9. [CrossRef] [PubMed]

69. Gong, J.; Fields, M.A.; Moreira, E.F.; Bowrey, H.E.; Gooz, M.; Ablonczy, Z.; Del Priore, L.V. Differentiation of Human Protein-Induced Pluripotent Stem Cells toward a Retinal Pigment Epithelial Cell Fate. PLoS ONE 2015, 10, e0143272. [CrossRef] [PubMed]

70. Buchholz, D.E.; Hikita, S.T.; Rowland, T.J.; Friedrich, A.M.; Hinman, C.R.; Johnson, L.V.; Clegg, D.O. Derivation of Functional Retinal Pigmented Epithelium from Induced Pluripotent Stem Cells. Stem Cells 2009, 27, 2427-2434. [CrossRef] [PubMed]

71. Carr, A.J.; Vugler, A.A.; Hikita, S.T.; Lawrence, J.M.; Gias, C.; Chen, L.L.; Buchholz, D.E.; Ahmado, A.; Semo, M.; Smart, M.J.; et al. Protective Effects of Human iPS-Derived Retinal Pigment Epithelium Cell Transplantation in the Retinal Dystrophic Rat. PLoS ONE 2009, 4, e8152. [CrossRef] [PubMed]

72. Singh, R.; Phillips, M.J.; Kuai, D.; Meyer, J.; Martin, J.M.; Smith, M.A.; Perez, E.T.; Shen, W.; Wallace, K.A.; Capowski, E.E.; et al. Functional Analysis of Serially Expanded Human iPS Cell-Derived RPE Cultures. Investig. Ophthalmol. Vis. Sci. 2013, 54, 6767-6778. [CrossRef] [PubMed]

73. Westenskow, P.; Sedillo, Z.; Barnett, A.; Friedlander, M. Efficient Derivation of Retinal Pigment Epithelium Cells from Stem Cells. J. Vis. Exp. 2015, 97, e52214. [CrossRef] [PubMed]

74. Okamoto, S.; Takahashi, M. Induction of Retinal Pigment Epithelial Cells from Monkey iPS Cells. Investig. Ophthalmol. Vis. Sci. 2011, 52, 8785-8790. [CrossRef] [PubMed]

75. Kamao, H.; Mandai, M.; Okamoto, S.; Sakai, N.; Suga, A.; Sugita, S.; Kiryu, J.; Takahashi, M. Characterization of Human Induced Pluripotent Stem Cell-Derived Retinal Pigment Epithelium Cell Sheets Aiming for Clinical Application. Stem Cell Reports 2014, 2, 205-218. [CrossRef] [PubMed]

76. Fields, M.A.; Bowrey, H.E.; Gong, J.; Ablonczy, Z.; Del Priore, L.V. Retinoid Processing in Induced Pluripotent Stem Cell-Derived Retinal Pigment Epithelium Cultures. Prog. Mol. Biol. Transl. Sci. 2015, 134, 477-490. [PubMed] 
77. Li, Y.; Tsai, Y.T.; Hsu, C.W.; Erol, D.; Yang, J.; Wu, W.H.; Davis, R.J.; Egli, D.; Tsang, S.H. Long-Term Safety and Efficacy of Human-Induced Pluripotent Stem Cell (iPS) Grafts in a Preclinical Model of Retinitis Pigmentosa. Mol. Med. 2012, 18, 1312-1319. [PubMed]

78. Westenskow, P.D.; Bucher, F.; Bravo, S.; Kurihara, T.; Feitelberg, D.; Paris, L.P.; Aguilar, E.; Lin, J.H.; Friedlander, M. iPSC-Derived Retinal Pigment Epithelium Allografts Do Not Elicit Detrimental Effects in Rats: A Follow-Up Study. Stem Cells Int. 2016, 2016, 8470263. [CrossRef] [PubMed]

79. Yvon, C.; Ramsden, C.M.; Lane, A.; Powner, M.B.; da Cruz, L.; Coffey, P.J.; Carr, A.J. Using Stem Cells to Model Diseases of the Outer Retina. Comput. Struct. Biotechnol. J. 2015, 13, 382-389. [CrossRef] [PubMed]

80. Singh, R.; Shen, W.; Kuai, D.; Martin, J.M.; Guo, X.; Smith, M.A.; Perez, E.T.; Phillips, M.J.; Simonett, J.M.; Wallace, K.A.; et al. iPS Cell Modeling of Best Disease: Insights into the Pathophysiology of an Inherited Macular Degeneration. Hum. Mol. Genet. 2013, 22, 593-607. [CrossRef] [PubMed]

81. Tucker, B.A.; Solivan-Timpe, F.; Roos, B.R.; Anfinson, K.R.; Robin, A.L.; Wiley, L.A.; Mullins, R.F.; Fingert, J.H. Duplication of TBK1 Stimulates Autophagy in iPSC-Derived Retinal Cells from a Patient with Normal Tension Glaucoma. J. Stem Cell Res. Ther. 2014, 3, 161. [CrossRef] [PubMed]

82. Nguyen, H.V.; Li, Y.; Tsang, S.H. Patient-Specific iPSC-Derived RPE for Modeling of Retinal Diseases. J. Clin. Med. 2015, 4, 567-578. [CrossRef] [PubMed]

83. Li, Y.; Wu, W.H.; Hsu, C.W.; Nguyen, H.V.; Tsai, Y.T.; Chan, L.; Nagasaki, T.; Maumenee, I.H.; Yannuzzi, L.A.; Hoang, Q.V.; et al. Gene Therapy in Patient-Specific Stem Cell Lines and a Preclinical Model of Retinitis Pigmentosa with Membrane Frizzled-Related Protein Defects. Mol. Ther. 2014, 22, 1688-1697. [CrossRef] [PubMed]

84. Klein, R.; Peto, T.; Bird, A.; Vannewkirk, M.R. The Epidemiology of Age-Related Macular Degeneration. Am. J. Ophthalmol. 2004, 137, 486-495. [CrossRef] [PubMed]

85. Paik, D.C.; Dillon, J.; Galicia, E.; Tilson, M.D. The Nitrite/Collagen Reaction: Non-Enzymatic Nitration as a Model System for Age-Related Damage. Connect. Tissue Res. 2001, 42, 111-122. [CrossRef] [PubMed]

86. Swaroop, A.; Chew, E.Y.; Rickman, C.B.; Abecasis, G.R. Unraveling a Multifactorial Late-Onset Disease: From Genetic Susceptibility to Disease Mechanisms for Age-Related Macular Degeneration. Annu. Rev. Genom. Hum. Genet. 2009, 10, 19-43. [CrossRef] [PubMed]

87. De Vos, J.; Bouckenheimer, J.; Sansac, C.; Lemaitre, J.M.; Assou, S. Human Induced Pluripotent Stem Cells: A Disruptive Innovation. Curr. Res. Transl. Med. 2016, 64, 91-96. [CrossRef] [PubMed]

88. Kimbrel, E.A.; Lanza, R. Current Status of Pluripotent Stem Cells: Moving the First Therapies to the Clinic. Nat. Rev. Drug Discov. 2015, 14, 681-692. [CrossRef] [PubMed]

89. Klassen, H. Stem Cells in Clinical Trials for Treatment of Retinal Degeneration. Expert Opin. Biol. Ther. 2016, 16, 7-14. [CrossRef] [PubMed]

90. McGill, T.J.; Cottam, B.; Lu, B.; Wang, S.; Girman, S.; Tian, C.; Huhn, S.L.; Lund, R.D.; Capela, A. Transplantation of Human Central Nervous System Stem Cells - Neuroprotection in Retinal Degeneration. Eur. J. Neurosci. 2012, 35, 468-477. [CrossRef] [PubMed]

91. Kawamata, S.; Kanemura, H.; Sakai, N.; Takahashi, M.; Go, M.J. Design of a Tumorigenicity Test for Induced Pluripotent Stem Cell (iPSC)-Derived Cell Products. J. Clin. Med. 2015, 4, 159-171. [CrossRef] [PubMed]

92. Reardon, S.; Cyranoski, D. Japan Stem-Cell Trial Stirs Envy. Nature 2014, 513, 287-288. [CrossRef] [PubMed]

93. Yoshihara, M.; Hayashizaki, Y.; Murakawa, Y. Genomic Instability of iPSCs: Challenges Towards Their Clinical Applications. Stem Cell Rev. 2016. [CrossRef] [PubMed]

94. Chakradhar, S. An Eye to the Future: Researchers Debate Best Path for Stem Cell-Derived Therapies. Nat. Med. 2016, 22, 116-119. [CrossRef] [PubMed]

95. Garber, K. Riken Suspends First Clinical Trial Involving Induced Pluripotent Stem Cells. Nat. Biotechnol. 2015, 33, 890-891. [CrossRef] [PubMed]

96. Sugita, S.; Iwasaki, Y.; Makabe, K.; Kamao, H.; Mandai, M.; Shiina, T.; Ogasawara, K.; Hirami, Y.; Kurimoto, Y.; Takahashi, M. Successful Transplantation of Retinal Pigment Epithelial Cells from MHC Homozygote iPSCs in Mhc-Matched Models. Stem Cell Rep. 2016, 7, 635-648. [CrossRef] [PubMed]

97. Sugita, S.; Iwasaki, Y.; Makabe, K.; Kimura, T.; Futagami, T.; Suegami, S.; Takahashi, M. Lack of T Cell Response to iPSC-Derived Retinal Pigment Epithelial Cells from HLA Homozygous Donors. Stem Cell Rep. 2016, 7, 619-634. [CrossRef] [PubMed] 
98. Riken to Resume Retinal iPS Transplant Study in Cooperation with Kyoto University. The Japan Times. 7 June 2016. Available online: http:/ / www.japantimes.co.jp/news/2016/06/07/national/science-health/ riken-resume-retinal-iPS-transplantation-cooperation-kyoto-university/\#.WEdkwH_YWpo (accessed on 26 October 2016).

99. Kanemura, H.; Go, M.J.; Shikamura, M.; Nishishita, N.; Sakai, N.; Kamao, H.; Mandai, M.; Morinaga, C.; Takahashi, M.; Kawamata, S. Tumorigenicity Studies of Induced Pluripotent Stem Cell (iPSC)-Derived Retinal Pigment Epithelium (RPE) for the Treatment of Age-Related Macular Degeneration. PLoS ONE 2014, 9, e85336. [CrossRef] [PubMed]

100. Trounson, A.; DeWitt, N.D. Pluripotent Stem Cells Progressing to the Clinic. Nat. Rev. Mol. Cell Biol. 2016, 17, 194-200. [CrossRef] [PubMed]

(C) 2016 by the authors; licensee MDPI, Basel, Switzerland. This article is an open access article distributed under the terms and conditions of the Creative Commons Attribution (CC-BY) license (http://creativecommons.org/licenses/by/4.0/). 